Izv. prof. dr. sc. Andrijana Bilić

Pravni fakultet Sveučilišta u Splitu

Domagoj Mokrović, mag. iur.

\title{
OČUVANJE RADNIH MJESTA U VRIJEME KRIZE IZAZVANE PANDEMIJOM COVID-A 19
}

\author{
$U D K: 331.57: 616.2-036.21$ \\ DOI: $10.31141 /$ zrpfs.2021.58.140.525 \\ Izvorni znanstveni rad \\ Primljeno: 25. 1. 2021
}

\begin{abstract}
U radu autori razmatraju problematiku očuvanja radnih mjesta uslijed krize izazvane izbijanjem pandemije COVID-a 19. U tu svrhu analiziraju preporuke Međunarodne organizacije rada i Europske konfederacije sindikata te daju komparativni prikaz mjera za očuvanje radnih mjesta nekoliko nacionalnih pravnih poredaka. U zaključnim razmatranjima iznose postojeće i potencijalne probleme koji proizlaze iz primjene mjera te daju rješenja de lege ferenda.
\end{abstract}

Ključne riječi: COVID-19, mjere za očuvanje radnih mjesta, Međunarodna organizacija rada, Europska unija, Republika Hrvatska

\section{UVOD}

Svjetska tržišta rada kroz povijest su često bila obilježena kolektivnim otpuštanjima radnika, najčešće prouzročenih ekonomskim krizama. U recentnoj povijesti takav primjer predstavlja ekonomska kriza 2008. godine. Naime, usporavanje ekonomskog rasta odrazilo se, prije svega, na smanjenu količinu proizvodnje, a time posredno i na smanjenje potrebe za radnom snagom. Kao takva, ova je kriza neizostavno imala negativne posljedice na globalno tržište rada. Prema podacima Međunarodne organizacije rada (u daljnjem tekstu: MOR), ta je kriza, nakon 4 godine uzastopnog pada stope nezaposlenosti, na globalnoj razini uzrokovala porast stope sa 5,7 u 2007. na 6,6 \% u 2009. godini što se pokazalo kao najveći porast još od 1998. godine. ${ }^{1}$ U Republici Hrvatskoj, broj nezaposlenih je u periodu od 2008. do 2013. godine skočio sa 236.741 na $345.112^{2}$ što predstavlja najveću brojku nezaposlenih od njenog osamostaljenja.

Tijekom recesije poduzeća u Europskoj uniji često su primjenjivala mjeru skraćivanja radnog vremena kako bi se prilagodila smanjenoj potražnji na tržištu

1 International Labour Office, Global Employment Trends 2010; Ženeva, siječanj 2010., dostupno na: http://www.ilo.org/public/libdoc/ilo/P/09332/09332(2010-January).pdf (pristupljeno 5. VII. 2020.).

2 Hrvatski zavod za zapošljavanje, Statistika Hrvatskog zavoda za zapošljavanje, dostupno na: https://statistika.hzz.hr/Statistika.aspx?tipIzvjestaja=1 (pristupljeno 5. VII. 2020.). 
Izv. prof. dr. sc. Andrijana Bilić i Domagoj Mokrović, mag. iur.: Očuvanje radnih mjesta u vrijeme krize... Zbornik radova Pravnog fakulteta u Splitu, god. 58, 2/2021, str. 525-552

proizvoda odnosno usluga i istodobno sačuvala svoje najvrednije resurse - ljudske resurse. Mnoge europske države putem posebnih programa poticale su ovu mjeru radi očuvanja radnih mjesta. Takvih pokušaja bilo je i u Hrvatskoj, no bez očekivanih rezultata. ${ }^{3}$

U trenutku pisanja ovoga rada u začetku je nova ekonomska kriza prouzročena pandemijom bolesti COVID-19. ${ }^{4}$ Stručnjaci upozoravaju da je u pitanju kriza bez presedana, kako glede svojih manifestacija, tako i brzine širenja. Iako je sličan uzrok postojao 1918. godine u vidu španjolske gripe, gospodarske prilike tada i danas, uz globalizaciju i rapidan tehnološki razvoj, nisu usporedive. ${ }^{5}$ Radi suzbijanja širenja virusa te zaštite ljudskih života vlade su poduzele mjere bez presedana. No, poduzeti lockdown i druge restriktivne mjere u bitnome su imale, i još uvijek imaju, utjecaj na gospodarstvo, tržište rada ${ }^{6}$ i ljudske živote. ${ }^{7}$ Naime, pod utjecajem krize izazvane pandemijom COVID-a 19, poslovanje u različitim gospodarskim sektorima suočava se s katastrofalnim gubicima koji predstavljaju ugrozu za njihovo djelovanje i solventnost, posebice kada su u pitanju mali poslodavci. S druge strane, oko $81 \%$ radnika širom svijeta osjeća negativne posljedice, bilo u vidu smanjenja ili gubitka prihoda odnosno otkaza kao ultima ratio ${ }^{8}$ Sektori koji su najviše izloženi krizi jesu trgovina na veliko i malo, prijevoz i skladištenje, djelatnosti pružanja smještaja te pripreme i usluživanja hrane, prerađivačka industrija, umjetnost, zabava i rekreacija te poslovanje nekretninama.

Utjecaj ovih mjera u velikoj mjeri ovisi o postojećim nejednakostima na tržištu rada i o intervencijama vlada. ${ }^{9}$ Posebno su ugrožene skupine radnici u neformalnoj

3 Hrvatski sabor je u srpnju 2009. godine donio Zakon o potpori za očuvanje radnih mjesta s ciljem očuvanja radnih mjesta kod poslodavaca koji su nakon 31. srpnja 2008. godine imali iskazan gubitak u svojem poslovanju nastao kao posljedica gospodarske i financijske krize.

4 Prassl, A. A., Cloyne, J., Costa Dias, M., Parey, M., Zilak, J. M., ,The COVID $\square 19$ Economic Crisis“, FISCAL STUDIES, vol. 41, no. 3, pp. 489-492 (2020.); Global Economic Effects of COVID-19, Jackson, James K.; Weiss, Martin A.; Schwarzenberg, Andres B.; Nelson, Rebecca M., Heinonline, luebook 21st ed. 11 (October 27, 2020).

5 Jungvirth, G., Koliko će recesije iz, 2008. i 2020. biti drugačije i zašto je to važno, 24. III. 2020., dostupno na: https://www.poslovni.hr/financije/kako-ce-recesije-iz-2008-i-2020-biti-drugacije-i-zasto-jeto-vazno-4221453 (pristupljeno 2. VIII. 2020.).

6 Costa Dias, M., Joyce, R., Postel-Vinay, F., Xiaowei, X., „The Challenges for Labour Market Policy during the COVID-19 Pandemic“, FISCAL STUDIES, vol. 41, no. 2, pp. 371-382 (2020.).

T. von Wachter, „Lost Generations: Long-Term Effects of the COVID-19 Crisis on Job Losers and Labour Market Entrants, and Options for Policy“, FISCAL STUDIES, 2020., vol. 41, no. 3, str. 549-590; Hupkau, C., Petrongolo, B., Work, „Care and Gender during the COVID-19 Crisis“, FISCAL STUDIES, 2020., vol. 41, no. 3, str. 623-651.

8 Do sredine svibnja 2020. godine $94 \%$ radne snage živjelo je i radilo u zemljama u kojima je predstavljena barem neka mjera zatvaranja poduzeća (ILO, 2020., International Labour Organisation, COVID-19 monitor, 4. ed., 27. May 2020.), uz napomenu da je nekih 1,25 milijardi radnika zaposleno u sektorima visokog rizika (ILO, 2020, International Labour Organisation, COVID-19 monitor, 2.ed., 7. April 2020; Houston, D., „Local resistance to rising unemployment in the context of the COVID $\square 19$ mitigation policies across Great Britain“, Reg Sci Policy Pract. 2020; 12: 1189-1209.

9 Sagan, A., Schuller, C., „Covid-19 and Labour Law in Germany“, European Developments, European Labour Law Journal, Vol. 11, Issue 3 (September 2020), str. 292-297; Mangan, D., „Covid-19 and Labour Law in Ireland“, European Developments, European Labour Law Journal, Vol. 11, Issue 3 (September 2020), str. 298-305; Mangan, D., „Covid-19 and Labour Law in the United Kingdom“, European Developments, European Labour Law Journal, Vol. 11, Issue 3 (September 2020), str. $332-347$. 
Izv. prof. dr. sc. Andrijana Bilić i Domagoj Mokrović, mag. iur.: Očuvanje radnih mjesta u vrijeme krize... Zbornik radova Pravnog fakulteta u Splitu, god. 58, 2/2021, str. 525-552

ekonomiji, mladi radnici, žene te radnici zaposleni u SMS-tvrtkama. ${ }^{10}$ Već pri samoj naznaci početka krize, radnici su se gotovo odmah našli na meti poslodavaca na način da ih proglašavaju gospodarskim viškovima te im radni odnosi prestaju poslovno uvjetovanim otkazima. Dolazi do povećanja stope nezaposlenosti koja se na svjetskoj razini popela na $8,4 \%$ u travnju 2020 . godine, odnosno za 2,9 postotna poena u odnosu na prethodni mjesec. ${ }^{11}$ Istovremeno, u Republici Hrvatskoj, broj nezaposlenih u travnju 2020., prema podacima Hrvatskog zavoda za zapošljavanje (u daljnjem tekstu: HZZ), viši je za 15.773 nego prethodnoga mjeseca te za 28.144 nego u travnju 2019. Dakle, u travnju 2020. godine nezaposlenost je povećana za $11,0 \%$ u usporedbi s prethodnim mjesecom, te za $21,5 \%$ u usporedbi s istim mjesecom 2019. godine. ${ }^{12}$

Broj izgubljenih radnih mjesta u 2021. godini kritično će ovisiti o dva čimbenika: razvoju pandemije te poduzetim mjerama kojima je svrha ublažiti njen utjecaj, kako na zdravlje i živote stanovništva, tako i na gospodarski rast i razvoj. U svakom slučaju, zabrinjavajuće su i kratkoročne i dugoročne prognoze. Prema kratkoročnim prognozama, mnogi radnici koji su ostali bez posla neće u skoroj budućnosti biti u mogućnosti pronaći novo zaposlenje. Dugoročno gledano, navedeni će izazovi biti od ogromnog utjecaja na borbu protiv siromaštva i nejednakosti. ${ }^{13}$ Štoviše, ovakva situacija dodatno nadolijeva ulje na vatru nezadovoljstva i tjeskobe koji među radnicima vladaju na tržištu rada već više od desetljeća uslijed povećane fleksibilizacije radnih odnosa. ${ }^{14}$

Institucije odnosno propisi na tržištu rada općenito se uvode kako bi se poboljšala zaposlenost i sigurnost prihoda radnika putem novčanih naknada i/ili programa socijalne sigurnosti. Stoga, tema je ovoga rada promotriti u kojoj su mjeri u okviru aktualne pandemije očuvana radna mjesta, odnosno koliko se često javljaju poslovno uvjetovani otkazi, mogu li se i na koji način izbjeći te uporabom kojih su

10 Blundell, R., Costa Dias M., Joyce, R., Xiaowei, X., „COVID $\square 19$ and Inequalities“, FISCAL STUDIES, vol. 41, no. 2, *pp. 291-319 (2020.). Radnici zaposleni u neformalnoj ekonomiji samo su u prvom mjesecu krize uzrokovane pandemijom COVID-a 19 imali pad od $60 \%$ zarade. Među mladim radnicima četvoro od njih deset zaposleno je u sektorima koji su najviše pogođeni ovom krizom, a kad dodamo tome prekid u njihovu obrazovanju i profesionalnoj izobrazbi, opravdano ih možemo nazvati generacijom lockdowna. Žene su disproporcionalno zaposlene u sektorima kritično pogođenima krizom, u prvom redu uslužnim djelatnostima, ali također u neplaćenom kućnom radu (ILO, 2020, The COVID-19 response: Getting gender equality right for the better future for woman in work.

11 OECD. Unemployment rates, OECD - Updated: June 2020, dostupno na: http://www.oecd.org/ newsroom/unemployment-rates-oecd-update-june-2020.htm (pristupljeno 2. VIII. 2020.).

12 Hrvatski zavod za zapošljavanje. Mjesečni statistički bilten Hrvatskog zavoda za zapošljavanje za travanj 2020., svibanj 2020., dostupno na: https://www.hzz.hr/content/stats/0420/HZZ_stat_ bilten_04_2020.pdf (pristupljeno 5. VII. 2020.).

13 Prije izbijanja krize 7,1 \% svjetske radne snage živjelo je u ekstremnom siromaštvu (ILOSTAT, https://ilostat.ilo.org./). Žene su imale upola manje šanse od muškaraca u pronalasku zaposlenja te su bile u većoj mjeri zaposlene u slabo plaćenim i nezaštićenim poslovima. Oko 267 milijuna mladih nije bilo zaposleno niti pohađalo obrazovanje ili profesionalno usavršavanje (ILOSTAT, https://ilostat.ilo.org./). U mnogim državama sindikati se suočavaju s represijom u radu, dok je milijunima radnika onemogućeno sindikalno koaliranje i kolektivno pregovaranje (ITUC, 2019., ITUC global rights indeks, https://www. ituc-csi.org/IMG/pdf/2019-06-ituc-global-rights-index-2019-report-en-2.pdf).

14 Bilić, A., „Fleksibilni oblici rada i radno pravo“, Zb. Prav. fak. Sveuč. Rij. (1991.), v. 30, br. 2 , 2009., str. 920-942, str. 921-922. 
mjera države odlučile riješiti taj problem. Činjenica jest da, bez obzira na to koji dio svijeta ili koji sektor bio pogođen, kriza ima dramatičan i sveobuhvatan utjecaj na svijet rada. Stoga se političke mjere trebaju fokusirati na trenutačno olakšavanje pozicije radnicima i poslodavcima na tržištu rada osiguravajući sredstva za život i ekonomski održivo poslovanje, posebice u djelatnostima teško pogođenima pandemijom te u zemljama u razvoju. ${ }^{15}$ Iz navedenih razloga ograničeni javni resursi trebaju se koristiti na način koje će ohrabriti poslodavce da zadrže postojeća i/ili kreiraju nova radna mjesta.

U daljnjem tekstu autori, nakon pregleda preporuka MOR-a i mjera donesenih na razini Europske unije glede očuvanja radnih mjesta, daju prikaz ovih mjera donesenih u Republici Hrvatskoj, komparirajući ih s rješenjima kojima su se priklonile neke države (Republike Slovenija, Austrija, Njemačka i Finska te Ujedinjeno Kraljevstvo) sa svrhom kako bi na koncu, uz eventualnu kritiku hrvatskih nacionalnih rješenja de lege lata, ponudili rješenja de lege ferenda. Nesnalaženje mnogih zemalja pri uređenju mjera zaštite prava radnika i očuvanja radnih mjesta rezultira oprečnim mišljenjima stručnjaka kako tom problemu pristupiti.

\section{OČUVANJE RADNIH MJESTA U VRIJEME PANDEMIJE COVID-A 19}

\subsection{Mjere za očuvanje radnih mjesta}

Institucije odnosno propisi na tržištu rada općenito se uvode kako bi se poboljšala zaposlenost i sigurnost prihoda radnika putem novčanih naknada i/ili programa socijalne sigurnosti. Stoga, tema ovoga rada jest promotriti u kojoj su mjeri u okviru aktualne pandemije očuvana radna mjesta, odnosno koliko se često javljaju poslovno uvjetovani otkazi, mogu li se i na koji način izbjeći te uporabom kojih mjera su države odlučile riješiti taj problem. Činjenica jest da bez obzira na to koji dio svijeta ili koji sektor bio pogođen, kriza ima dramatičan i sveobuhvatan utjecaj na svijet rada. Stoga se političke mjere trebaju fokusirati na trenutačno olakšavanje pozicije radnicima i poslodavcima na tržištu rada osiguravajući sredstva za život i ekonomski održivo poslovanje, posebice u djelatnostima teško pogođenima pandemijom te zemljama u razvoju. Stoga se ograničeni javni resursi trebaju koristiti na način koji će ohrabriti poslodavce da zadrže postojeća i/ili kreiraju nova radna mjesta.

U ranim fazama razvoja krize COVID-a 19, mnoge su vlade u svrhu postizanja prethodno navedenih ciljeva modificirale postojeće sheme za očuvanje radnih mjesta te predstavile nove. Navedene sheme omogućavaju poslodavcima održanje likvidnosti i time zadržavanje zaposlenika, uključujući njihova znanja, vještine, talente i sposobnosti. Također omogućavaju brže uspostavljanje poslovanja čim

15 Detaljnije: Brent Orrell, A., Bishop, M. M., Hawkins, J., A Road Map to Reemployment in the COVID-19 Economy, empowering workers, employers, and states, American Enterprise Institute, July 2020. 
dođe do oporavka gospodarske aktivnosti, a da ne moraju proći postupak otpuštanja radnika, te u fazi gospodarskog oporavka ponovno zapošljavanje i profesionalnu izobrazbu novih radnika. Međutim, nužno je mjerama postići ravnotežu između adekvatne potpore za očuvanje radnih mjesta koja su privremeno neisplativa i ograničavanja primjene potpora za održanjem onih radnih mjesta koja bi se svakako očuvala ili za ona koja su neisplativa dugoročno gledajući.

Politike zapošljavanja i paketi za potporu poslodavcima i zaštitu radnicima od rizika nezaposlenosti, ali i razvoj novih mogućnosti zapošljavanja implementirane su u mnogim državama kao trenutačan odgovor na nastalu pandemiju. Najčešće korištene mjere jesu: sheme potpora za održavanje radnih mjesta, potpora plaća, inicijative za work-sharing i skraćivanje radnog vremena, privremena suspenzija plaćanja poreza ${ }^{16}$ i socijalnih davanja i sl. ${ }^{17}$

\subsection{Međunarodne i regionalne preporuke glede mjera za očuvanje radnih mjesta}

\subsubsection{Preporuke Međunarodne organizacije rada}

Već od pojave prvih znakova ugroze prava radnika iz radnog odnosa prouzročenih pandemijom, MOR počinje s donošenjem preporuka, publiciranjem izvješća $\mathrm{i}$ podataka te pružanjem odgovora na brojne pristigle upite na svoju adresu, a sve u svrhu promicanja očuvanja prava radnika unatoč nepovoljnim situacijama na tržištu za većinu poslodavaca. U posljednjem se izvješću ističe da mjere za sprečavanje širenja koronavirusa imaju štetne posljedice za otprilike $81 \%$ radnika diljem svijeta, odnosno otprilike 2,7 milijardi radnika. Sektori koji su najviše pogođeni krizom jesu trgovina na veliko i malo, prijevoz i skladištenje, djelatnosti pružanja smještaja te pripreme i usluživanja hrane, prerađivačka industrija, umjetnost, zabava i rekreacija te poslovanje nekretninama. Na mjesečnoj bazi publicira izvješće pod nazivom „ILO monitor: COVID-19 i poslovni svijet"18 $\mathrm{u}$ kojem daje prikaz aktualnih podataka, statistike i predviđanja vezanih uz kretanja na tržištu rada.

Najznačajnije preporuke iznosi u dokumentu naziva „Politički okvir za suočavanje sa gospodarskim i socijalnim utjecajem krize uzrokovane COVID-om 19 “. ${ }^{19}$ Spomenuti politički okvir mora počivati na 4 temeljna stupa: 1) stimuliranje gospodarstva i zapošljavanja, 2) podržavanje poduzeća, poslova i prihoda, 3) zaštita

16 Gravelle, J. G.; Marples, D. J., Fiscal Policy and Recovery from the COVID-19 Recession (R46460), HeinOnline, Bluebook 21st ed. 11 (July 29, 2020.)

17 Blanchard, O., Philippon, T., Pisani-Ferry, J., A new policy toolkit is needed as countries exit COVID-19 lockdowns, Policy contribution, issue no. 12, June 2020., str. Bruegel.

18 International Labour Organization. ILO Monitor: COVID-19 and the world of work. Fifth edition, 30. VI. 2020., dostupno na: https:/www.ilo.org/wcmsp5/groups/public/@dgreports/@ dcomm/ documents/briefingnote/wcms_749399.pdf (pristupljeno 4. VIII. 2020.).

19 International Labour Organization, A policy framework for tackling the economic and social impact of the COVID-19 crisis, svibanj 2020., dostupno na: https://www.ilo.org/wcmsp5/groups/public/@ dgreports/@dcomm/documents/briefingnote/wcms_745337.pdf (pristupljeno 4. VIII. 2020.). 
radnika na radnom mjestu te 4) oslanjanje na socijalni dijalog radi iznalaženja adekvatnih rješenja.

Predmet su našeg interesa u ovom radu mjere koje se nalaze u spomenutom drugom stupu pod nazivom „mjere za održanje zaposlenja“ (engl. employment retention measures) koje smatra ključnima u sprečavanju otkazivanja ugovora o radu radnicima te poticanje poslodavaca da zadrže radnike na radnim mjestima. Temeljni cilj tih mjera jest zadržati radnike na platnim listama kako bi poduzeća bila spremna nastaviti svoje djelatnosti čim se mjere država, čija je svrha sprečavanje širenja virusa, ublaže ili ukinu. Kao primjeri takvih mjera navode se skraćivanje radnog tjedna, subvencije plaća, privremene suspenzije plaćanja određenih poreza i davanja te uvjetovanje raznih oblika potpora poslodavcima zadržavanjem radnika na radnim mjestima. Poslodavci bi mogli primati potpore ako jamče da se otpušteni radnici mogu vratiti na dotadašnje radno mjesto kada se situacija poboljša dok bi tvrtke koje imaju širok spektar proizvodnje radnike mogle privremeno prerasporediti na radna mjesta u kojima je povećana proizvodnja. MOR smatra kako su takve mjere prikladne poduzećima svih veličina te navodi kako su već implementirane u europskim zemljama.

Poseban naglasak stavlja na tzv. ,,work sharing“, odnosno na skraćivanje radnog vremena tako da se smanjeni obim posla rasporedi na jednaki broj radnika kako bi se izbjegli otkazi. Pri tom je nužno, u cilju osiguranja pravednosti, urediti mnoga pitanja, primjerice: koji radnici će biti obuhvaćeni takvom mjerom? Do kolikog će smanjenja radnih sati, a time i plaća, doći? Koliko će radni sati, a sukladno tome i plaće, biti smanjeni? Koliko će takvo uređenje biti na snazi? Odgovore na ova pitanja MOR vidi u dinamičnom socijalnom dijalogu između udruga poslodavaca i sindikata kako bi rješenja bila utemeljena na njihovom međusobnom konsenzusu.

MOR ističe kako mjere za očuvanje radnih mjesta mogu biti efikasnije ako se usklade sa stručnim osposobljavanjem radnika za vrijeme njihova trajanja. Ideja je takvog uređenja da za vrijeme smanjenja obima posla, odnosno skraćenog radnog vremena, radnici kroz različite vidove edukacije (online, na radnom mjestu, savjetovanjima) preostalo vrijeme do svog ugovorenog radnog vremena (punog ili nepunog) provedu na usavršavanju postojećih i/ili usvajanju novih profesionalnih vještina. Na ovaj bi način po okončanju privremenih mjera bili u mogućnosti djelotvornije obavljati dotadašnje poslove ili lakše pronalazili druga radna mjesta ako se za time ukaže potreba.

Mogućnost i domena primjene mjera za očuvanje radnih mjesta ovisit će o sustavu socijalnog osiguranja pojedine države, kao i o obimu osiguranja za slučaj nezaposlenosti. Navodi se kako se većina država koje su implementirale mjere „work sharing“ oslanja na državna osiguranja za slučaj nezaposlenosti koja se dopunjuju iz državnih proračuna, dok su se druge opredijelile za subvencioniranje plaća izravno iz poreza. ${ }^{20}$ No takav sustav teško je provediv u državama u razvoju te

20 Primjerice, u Danskoj, Vlada se obvezala financirati $75 \%$ plaća do 23.000 kruna (otprilike 3000 eura) ako se tvrtka suzdrži od proglašavanja radnika viškom. 
Izv. prof. dr. sc. Andrijana Bilić i Domagoj Mokrović, mag. iur.: Očuvanje radnih mjesta u vrijeme krize... Zbornik radova Pravnog fakulteta u Splitu, god. 58, 2/2021, str. 525-552

onima težeg ekonomskog statusa. Rješenje za takve države MOR vidi u osiguravanju privremenih poslova, primarno kroz programe javnog rada. ${ }^{21}$

Na koncu MOR naglašava za nužnost da mjere očuvanja radnih mjesta kao ciljanu skupinu obuhvate migrante i izbjeglice jer jedino osiguravanje jednakih mogućnosti za sve može dovesti do povećane produktivnosti te smanjenja društvenih tenzija.

No, usprkos izvanrednoj situaciji prouzročenoj pandemijom, MOR podsjeća na temeljna prava radnika koja se ne smiju kršiti:22

1. radnici čiji je radni odnos prestao poslovno uvjetovanim otkazom radi zdravstvenih i sigurnosnih razloga imaju pravo na otpremninu ili druge naknade, sukladno Konvenciji br. 158 o prestanku radnog odnosa; ${ }^{23}$

2. u slučaju kolektivnog viška radnika poslodavac je dužan predstavnicima radnika pružiti relevantne informacije i razloge za otkaz te im pružiti mogućnost za razmatranje mjera kako bi se mogli izbjeći otkazi, sukladno Konvenciji br. 158 o prestanku radnog odnosa; ${ }^{24}$

3. potrebno je otkloniti ili, koliko je to moguće, umanjiti (bez štetnog djelovanja na poslovanje tvrtke) prestanak radnih odnosa zbog gospodarskih ili sličnih razloga te gdje je to moguće savjetovati se s nadležnim tijelima u iznalaženju rješenja glede razmatranih otkaza, sukladno Preporuci br. 166 o prestanku radnog odnosa: ${ }^{25}$

4. privremeni izostanak s radnog mjesta zbog bolesti ili obiteljskih odgovornosti ne predstavlja valjani razlog za prestanak radnog odnosa, sukladno Konvenciji br. 156 o jednakim mogućnostima i jednakom tretmanu radnika i radnica: radnici s obiteljskim obvezama; ${ }^{26}$

5. radnici koji nemaju primanja radi nemogućnosti pronalaska adekvatnog zaposlenja, pod određenim uvjetima imaju pravo na naknadu za nezaposlene, sukladno Konvenciji br. 102 o najnižim standardima socijalne sigurnosti:27

${ }^{21}$ Javni rad jest mjera čiji se program temelji na društveno korisnom radu koji inicira lokalna zajednica ili organizacije civilnog društva. Mora biti neprofitan i nekonkurentan postojećem gospodarstvu u tom području. - Preuzeto sa: http://mjere.hr/mjere/javni-rad/ (pristupljeno 5. VIII. 2020.).

22 International Labour Organization, ILO Standards and COVID-19 (coronavirus) FAQ - Key provisions of international labour standards relevant to the evolving COVID-19 outbreak, 29. V. 2020., dostupno na: https://www.ilo.org/wcmsp5/groups/public/---ed_norm/---normes/documents/ genericdocument/wcms_739937.pdf, (pristupljeno 4. VIII. 2020.).

23 Konvencija Međunarodne organizacije rada o prestanku radnog odnosa na inicijativu poslodavca (Termination of Employment Convention), 1982 (No. 158), čl. 12 vidi u: Buklijaš, B., Bilić, A., Međunarodno radno pravo, Split, 2006., str. 272-277; Valticos, N., Potobsky von G., International Labour Law, Kluwer Law and Taxation Publishers, Deventer-Boston, 1995., str. 146; Betten, L., International Labour Law, Kluwer, 1993., str. 225-226, „Prestanak radnog odnosa na inicijativu poslodavca prema konvenciji broj 158 Međunarodne organizacije rada“, Zbornik radova Pravnog fakulteta u Splitu, god. 30/1, 1993., str. 165-170.

24 Konvencija o prestanku radnog odnosa na inicijativu poslodavca, čl. 13.

25 Preporuka br. 166 o prestanku radnog odnosa (Termination of Employment Recommendation) iz 1982. (No. 166), čl. 19. Vidi: Valticos, N., Potobsky von G., International Labour Law, o. c., str. 144-166; Betten, L., International Labour Law, o. c., str. 227.

26 Workers with Family Responsibilities Conventions, 1981. (No. 156), čl. 8.

27 Konvenciji br. 102 o najnižim standardima socijalne sigurnosti (Social Security (Minimum Standards) Convention), 1952. (No. 102), Glava IV. 
6. pravo na isplatu naknade za nezaposlene imaju i 1) radnici čija su primanja smanjena radi privremenog smanjenja radnih sati, te 2) radnici kojima dođe do smanjenja plaće ili obustave njene isplate zbog privremene obustave rada, bez prekida radnog odnosa, zbog gospodarskih, tehnoloških ili sličnih razloga, sukladno Konvenciji br. 168 o promicanju zapošljavanja i zaštiti od nezaposlenosti; ${ }^{28}$

7. dužnost je država poticati produktivno i slobodno odabrano zanimanje te osigurati radnicima koji su ostali bez posla primjenu mjera zapošljavanja, uključujući stručno usavršavanje, s ciljem njihove reintegracije na tržište rada, sukladno Konvenciji br. 168 o promicanju zapošljavanja i zaštiti od nezaposlenosti. ${ }^{29}$

\subsubsection{Preporuke Europske konfederacije sindikata}

Na razini Europske unije, od europskih socijalnih partnera posebnu ulogu u isticanju nužnosti zaštite prava radnika odigrala je Europska konfederacija sindikata (dalje: ETUC). ${ }^{30}$ Kao socijalni partner na europskoj razini sa svojstvom reprezentativnosti može sudjelovati u kreiranju europskih kolektivnih ugovora, a time i stvaranja europskog radnog prava. Glede mjera za očuvanje radnih mjesta može na njihovo kreiranje utjecati putem raznih izjava, preporuka, mišljenja i otvorenih pisama državama i njihovim dužnosnicima.

U prvom redu, to je učinjeno putem otvorenog pisma o hitnim mjerama radi očuvanja poslova i zaštite prava radnika u Uniji upućenog institucijama EU-a u ožujku 2020. ${ }^{31}$ u kojem se ističe kako je situacija u kojoj se svijet nalazi bez presedana te da se prava radnika, unatoč upozorenjima, konstantno krše. Mjere koje ETUC smatra ključnima za održavanje radnih mjesta i izbjegavanje masovne nezaposlenosti - tzv. ,programi skraćenog radnog vremena “32 i sustav naknade plaća - na snazi su samo u nekim državama članicama, i to uz brojna ograničenja. Stoga od država članica traži hitnu implementaciju navedenih mjera. Posebno apelira na Europsku komisiju glede uspostave programa pod nazivom SURE (Support to mitigate Unemployment Risks in an Emergency) u svrhu zaštite radnika od otkaza i provedbu programa skraćenog radnog vremena, pri čemu bi Europsko vijeće,

28 Konvencija br. 168 o promicanju zapošljavanja i zaštiti od nezaposlenosti (Employment Promotion and Promotion Against Unemployment Convention), iz 1988. (No. 168.), čl. 10.

29 Ibid., čl. 7-9.

30 European Trade Union Confederation. Detaljinije o ovom socijalnom partneru vidi: Blanpain, R. European Labour Law, Wolters Kluwer, 2012., str. 129-136.

31 ETUC, Letter sent to EU Institutions on Emergency measures to save jobs and protect workers' rights in the European Union, 30. III. 2020., dostupno na: https://www.etuc.org/en/document/letter-senteu-institutions-emergency-measures-save-jobs-and-protect-workers-rights (pristupljeno 5. VIII. 2020.).

32 Programi skraćenog radnog vremena javni su programi kojima se poduzećima koja se suočavaju s gospodarskim poteškoćama omogućuje da privremeno smanje broj radnih sati, a zaposlenici za neodrađene sate dobivaju dohodovnu potporu države. Slični programi postoje i za nadoknadu dohotka samozaposlenim osobama u izvanrednim situacijama. - Preuzeto iz Prijedloga Uredbe Vijeća o uspostavi europskog instrumenta za privremenu potporu radi smanjenja rizika od nezaposlenosti u izvanrednoj situaciji (SURE) nakon izbijanja bolesti COVID-19 od 2. IV. 2020. 
Eurogrupa i Europska komisija trebali osigurati financiranje takvog programa. Osim toga, traži da Europska središnja banka, državne financijske institucije, Europska komisija i države članice tvrtkama, bankarskom i financijskom sektoru te uslugama od općeg interesa uvjetuju sve vrste financiranja - zabranom otpuštanja radnika, smanjenjem plaća i prava radnika te zabranom podjele dividendi korisnicima javnih sredstava.

Mjesec dana kasnije, u travnju 2020., izjavu ${ }^{33}$ je potpisao ETUC i više od 50 organizacija civilnog društva ${ }^{34}$ sa svrhom da se institucije Europske unije potaknu na poduzimanje mjera za zaštitu radnika, ne samo od otkaza, već i za zaštitu onih radnika čiji je obim posla uslijed pandemije značajno porastao, a posebice zdravstvenih radnika.

ETUC smatra kako važnu ulogu u očuvanju prava radnika ima i izmjena Smjernica o zaposlenju Europske komisije koje čine sastavni dio Europskog semestra, ${ }^{35}$ te njihovo bolje usklađenje s načelima izraženima u Europskom stupu socijalnih prava. ${ }^{36}{ }^{37}$ Ranije iznesena mjera programa skraćenog radnog vremena morala bi biti propisana u Smjernicama, dok bi države članice mjerama subvencioniranja plaća trebale pokriti barem $80 \%$ izgubljenog prihoda radnika te osigurati da radnici u poziciji rada u skraćenom radnom vremenu ili privremeno nezaposleni budu zaštićeni od trajnog otpuštanja za vrijeme trajanja pandemije. Dodatnu mjeru kojom bi se povećala potreba za radnicima i smanjila nezaposlenost ETUC vidi u investiranju u velike infrastrukturne projekte kao što su željeznice, elektrifikacija cesta te izgradnja kuća i stanova.

\subsubsection{SURE program Europske unije}

Dana 2. travnja 2020. Europska komisija iznijela je Prijedlog Uredbe Vijeća o uspostavi europskog instrumenta za privremenu potporu u cilju smanjenja rizika

33 ETUC, Civil Society \& Trade Union Statement For a Europe that cares for all - during the COVID-19 pandemic and beyond, 22. IV. 2020., dostupno na: https://www.etuc.org/en/document/civilsociety-trade-union-statement-europe-cares-all-during-covid-19-pandemic-and-beyond (pristupljeno 5. VIII. 2020.).

34 Pojam civilnog društva odnosi se na sve oblike društvenog djelovanja od strane pojedinaca ili grupa koje nisu povezane s državom niti ona njima upravlja. Organizacija civilnog društva jest organizacijska struktura čiji članovi služe općem interesu kroz demokratski proces te ima ulogu posrednika između javne vlasti i građana. - Preuzeto sa: https://eur-lex.europa.eu/summary/glossary/civil_society_organisation. html (pristupljeno 5. VIII. 2020.).

35 Europski semestar jest godišnji ciklus koordinacije gospodarske i proračunske politike u EU-u u kojem se usmjeruju zemlje EU-a prije nego što donesu političke odluke na nacionalnoj razini - preuzeto sa: https://ec.europa.eu/croatia/about-us/semester_hr (pristupljeno 5. VIII. 2020.).

36 Cilj je europskog stupa socijalnih prava uvažiti promjene na tržištu rada, a služit će kao smjernice za ponovnu uspostavu konvergencije u europodručju. Ta je inicijativa prvenstveno usmjerena na europodručje, ali otvorena je za sve države članice EU-a koje u njoj žele sudjelovati. - Preuzeto sa: https://ec.europa.eu/commission/priorities/deeper-and-fairer-economic-and-monetary-union/europeanpillar-social-rights_hr (pristupljeno 5. VIII. 2020.).

37 ETUC, ETUC position on the proposal for revision of the Employment Guidelines, 12. VI. 2020., preuzeto sa: https://www.etuc.org/en/document/etuc-position-proposal-revision-employment-guidelines (pristupljeno 5. VIII. 2020.). 
Izv. prof. dr. sc. Andrijana Bilić i Domagoj Mokrović, mag. iur.: Očuvanje radnih mjesta u vrijeme krize... Zbornik radova Pravnog fakulteta u Splitu, god. 58, 2/2021, str. 525-552

od nezaposlenosti u izvanrednoj situaciji (SURE) nakon izbijanja bolesti COVID19. ${ }^{38}$ Pravni temelj za uspostavu takvog programa nalazi se u članku 122. stavku 2. UFEU-a. ${ }^{39}$

U obrazloženju programa navodi se kako se on smatra dodatnim, privremenim instrumentom za financijsku pomoć Unije u vrijednosti do 100 milijardi eura koji će se dodjeljivati pogođenim državama članicama u obliku zajmova Unije. U okviru instrumenta SURE osigurat će se financijska pomoć povrh nacionalnih mjera i redovitih bespovratnih sredstava što se dodjeljuju za slične namjene iz Europskog socijalnog fonda. Konkretno, instrument SURE bit će druga crta obrane i služit će za potporu programa skraćenog radnog vremena i sličnih mjera kojima države članice štite radna mjesta, a time i zaposlene i samozaposlene osobe od rizika nezaposlenosti i gubitka dohotka.

Povlačenje financijske pomoći Unije u okviru instrumenta SURE bilo bi moguće na prijedlog Komisije Vijeću. Država članica trebala bi zatražiti potporu, a Komisija bi se prije nego što Vijeće dodijeli financijsku pomoć u okviru instrumenta SURE trebala savjetovati s dotičnom državom članicom kako bi procijenila razmjere (stvarnog ili očekivanog) iznenadnog i znatnog povećanja javnih rashoda u području zaštite radnih mjesta. Država članica bi pri podnošenju zahtjeva za potporu trebala dostaviti dokaze o tom iznenadnom i znatnom povećanju stvarnih, a potencijalno i planiranih rashoda. Ako su uvjeti za dodjelu financijske pomoći u okviru tog instrumenta ispunjeni, Vijeće kvalificiranom većinom donosi provedbenu odluku o njezinu odobravanju. Komisija i država članica korisnica sklapaju sporazum o provedbi. Pri ispitivanju iznenadnog povećanja rashoda relevantne operacije ostaju ograničene na hitne operacije u javnom sektoru poduzete za zaštitu radnih mjesta zbog pandemije bolesti COVID-19. Zahvaljujući tim zajmovima, države članice moći će financirati svoje povećane javne rashode namijenjene programima skraćenog radnog vremena i sličnim mjerama kojima se štite radna mjesta, a time i zaposlene i samozaposlene osobe od rizika nezaposlenosti.

Država članica može zatražiti financijsku pomoć Unije ako su se njezini stvarni, a potencijalno i planirani javni rashodi od 1 . veljače 2020. iznenada i znatno povećali zbog donošenja nacionalnih mjera koje se izravno odnose na programe skraćenog radnog vremena i sličnih mjera za rješavanje gospodarskih i socijalnih posljedica izvanrednih okolnosti prouzročenih pandemijom bolesti COVID-19.40

38 Prijedlog Uredbe Vijeća o uspostavi europskog instrumenta za privremenu potporu radi smanjenja rizika od nezaposlenosti u izvanrednoj situaciji (SURE) nakon izbijanja bolesti COVID-19 - dostupno na: https://eur-lex.europa.eu/legal-content/HR/TXT/HTML/?uri=CELEX:52020PC0139\&from=EN (pristupljeno 7. VIII. 2020.).

39 Čl. 122. st. 2. Pročišćene verzije Ugovora o Europskoj uniji i ugovora o funkcioniranju Europske unije (2016/C 202/01). Njime se omogućuje da Vijeće na prijedlog Komisije, pod određenim uvjetima, odobri financijsku pomoć Unije na privremenoj i ad hoc osnovi državi članici koja se nađe u poteškoćama ili joj prijete ozbiljne poteškoće zbog prirodnih katastrofa ili izvanrednih okolnosti koje su izvan njezine kontrole.

40 Prijedlog Uredbe Vijeća o uspostavi europskog instrumenta za privremenu potporu radi smanjenja rizika od nezaposlenosti u izvanrednoj situaciji (SURE) nakon izbijanja bolesti COVID-19, čl. 3. st. 1. 
Države članice mogu doprinijeti instrumentu pružanjem protujamstva za rizik koji snosi Unija, u obliku jamstava koja su neopoziva, bezuvjetna i na poziv. ${ }^{41}$ No, mogućnost korištenja sredstava iz programa javlja se tek nakon što sve države članice uplate svoj doprinos instrumentu u iznosu koji čini najmanje $25 \%$ iznosa iz članka 5. (maksimalni iznos od 100 milijardi eura), pod uvjetom da relativni udjeli doprinosa svake države članice u ukupnom iznosu doprinosa država članica odgovaraju relativnim udjelima država članica u ukupnom bruto nacionalnom dohotku Unije. ${ }^{42}$

Iako još mnogi detalji nisu razrađeni SURE programom, vidljiva je jasna namjera Europske unije da naglasak stavi na programe skraćenog radnog vremena kao temeljnu mjeru za očuvanje radnih mjesta. U prilog navedenoj mjeri ide brojna argumentacija: a) skraćivanje radnog vremena smanjuje broj otkaza u kriznim situacijama; b) sheme skraćivanja radnog vremena omogućavaju radnicima zadržavanje njihovih radnih mjesta i plaće koja im omogućava standard života, čak i u situacijama kada uslijed krize dođe do smanjenja određenog postotka plaće; c) sheme skraćivanja radnog vremena omogućavaju poslodavcima da u razdoblju ekonomske krize zadrže svoje radnike koji će po oporavku ekonomije odmah biti spremni za rad, umjesto da su prinuđeni otpustiti radnike, a po oporavku ekonomije proći postupak zapošljavanja novih radnika te njihove profesionalne izobrazbe; d) sheme skraćivanja radnog vremena pomažu poslodavcima da prilagode svoje radno vrijeme potrebama klijenata u situaciji cikličkih fluktuacija; e) gledano s makroekonomske perspektive, nije zanemariv utjecaj shema skraćivanja radnog vremena na stabilizaciju ekonomije budući da radnici zadržavaju svoja radna mjesta i prihode, a time imaju mogućnost trošenja većeg dijela svojih prihoda; f) za državu sheme skraćenog radnog vremena predstavljaju svojevrsnu uštedu jer je za njih jeftinije plaćanje shema skraćenog radnog vremena nego naknada za nezaposlene.

\subsubsection{Mjere Vlade Republike Hrvatske za očuvanje radnih mjesta}

Donošenjem Odluke o proglašenju epidemije bolesti COVID-19 ${ }^{43}$ dana 11. ožujka 2020. godine, za poslodavce, ali i radnike nastupile su brojne promjene u radnim odnosima te u načinu obavljanja rada. Radi lakšeg praćenja obveza i preporuka, Vlada RH izradila je i posebnu web-stranicu - koronavirus.hr. ${ }^{44}$ Djelatnosti koje nisu bile obuhvaćene zabranama rada u svrhu sprečavanja širenja virusa, morale su se obavljati uz praćenje i poštovanje odredbi Zakona o zaštiti pučanstva od

41 Prijedlog Uredbe Vijeća o uspostavi europskog instrumenta za privremenu potporu radi smanjenja rizika od nezaposlenosti u izvanrednoj situaciji (SURE) nakon izbijanja bolesti COVID-19, čl. 11. st. 1. i 2 .

42 Prijedlog Uredbe Vijeća o uspostavi europskog instrumenta za privremenu potporu radi smanjenja rizika od nezaposlenosti u izvanrednoj situaciji (SURE) nakon izbijanja bolesti COVID-19, čl. 12. st. 1.

43 Odluka o proglašenju epidemije bolesti COVID-19 prouzročene virusom SARS-CoV-2 od 11 . III. 2020., KLASA: 011-02/20-01/143, URBROJ: 534-02-01-2/6-20-01, preuzeto sa: https://zdravstvo.gov. $\mathrm{hr} /$ UserDocsImages/2020\%20CORONAVIRUS/ODLUKA\%200\%20PROGLA\%C5\%A0ENJU\%20 EPIDEMIJE\%20BOLESTI\%20COVID-19.pdf (pristupljeno 10. VIII. 2020.).

44 https://koronavirus.hr/ (pristupljeno: 10. VIII. 2020.) 
zaraznih bolesti, ${ }^{45}$ uputa Hrvatskog zavoda za javno zdravstvo te preporuka Stožera civilne zaštite RH i drugih nadležnih tijela. ${ }^{46} \mathrm{~S}$ tom svrhom, Ministarstvo rada i mirovinskoga sustava izdaje Uputu za poslodavce i radnike u kojoj sažima što je sve potrebno osigurati na radnom mjestu radi zaštite zdravlja i sigurnosti radnika ${ }^{47}$ (postavljanje fizičkih barijera, osiguranje udaljenosti između osoba, održavanje čistoće, osiguranje mjesta za dezinfekciju ruku itd.).

U slučaju poremećaja poslovnih aktivnosti poslodavca izazvanih epidemijom, Vlada RH preporuča poslodavcima u svrhu očuvanja zaposlenosti i radnih mjesta jednu od mogućnosti propisanih Zakonom o radu (dalje ZR): uvođenje nejednakog rasporeda radnog vremena; ${ }^{48}$ promjenu rasporeda radnog vremena radnika; preraspodjelu radnog vremena ${ }^{49}$ ugovaranje skraćivanja radnog vremena s radnikom (s punog na nepuno radno vrijeme) $;{ }^{50}$ donošenje odgovarajuće odluke koja bi imala utjecaj na organizaciju radnog vremena (npr. uvođenje smjenskog rada, ${ }^{51}$ organizacija rada u timovima i sl.); korištenje mogućnosti određivanja odmora i dopusta (plaćeni ${ }^{52}$ i neplaćeni ${ }^{53}$ ) te godišnji odmor. ${ }^{54}$

Uz poštovanje uvjeta propisanih ZR-om, na raspolaganju su i prekid rada (ali u tom slučaju ostaje obveza poslodavca na isplatu naknade place radnicima ${ }^{55}$ te opcija za koju su se mnogi odlučili - rad od kuće ( $\operatorname{rad}$ na izdvojenom mjestu rada). ${ }^{56}$

Vlada RH je 17. ožujka 2020. donijela paket od 63 mjere za pomoć gospodarstvu, ${ }^{57}$ među ostalima „Potpore za očuvanje radnih mjesta u sektorima pogođenima koronavirusom" u cilju izbjegavanja poslovno uvjetovanog otkaza kao ultima ratio koje poslodavcima stoji na raspolaganju. Mjere se periodički produljuju i mijenjaju, a u trenutku pisanja ovoga rada, na stranicama Hrvatskog zavoda za zapošljavanje (u daljnjem tekstu: HZZ) navode se sljedeće aktivne mjere: ${ }^{58}$ potpora za skraćivanje radnog vremena; potpora za očuvanje radnih mjesta u sektoru proizvodnje tekstila, odjeće, obuće, kože i drva; potpora za očuvanje radnih mjesta u djelatnostima pogođenima koronavirusom (COVID-om 19); potpora za očuvanje radnih mjesta u zaštitnim radionicama, integrativnim radionicama i radnim jedinicama za

45 Zakon o zaštiti pučanstva od zaraznih bolesti (NN 79/07, 113/08, 43/09, 130/17, 47/20).

46 https://koronavirus.hr/radni-odnosi-pitanja-i-odgovori/132, (pristupljeno: 10. VIII. 2020.)

47 Ministarstvo rada i mirovinskoga sustava. Uputa za poslodavce i radnike kod postupanja i provedbe mjera sigurnosti i zaštite zdravlja u okolnostima rizika od zarazne bolesti COVID-19, travanj 2020.

48 ZR, čl. 66.

49 ZR, čl. 67.

50 ZR, čl. 62, st. 7.

51 ZR, čl. 71.

52 ZR, čl. 86.

53 ZR, čl. 87.

54 ZR, čl. 85.

55 ZR, čl. 95.

56 ZR, čl. 17.

57 Hrvatska gospodarska komora, 63. Mjere za pomoć gospodarstvu, 17. III. 2020., dostupno na: https://www.hgk.hr/63-mjere-za-pomoc-gospodarstvu (pristupljeno 11. VIII. 2020.)

58 Potpore za očuvanje radnih mjesta, dostupno na: https://mjere.hr/potpore-ocuvanje-radnih-mjestadokumentacija-obrasci/ (pristupljeno 22. XI. 2020.). 
zapošljavanje osoba s invaliditetom čija je djelatnost pogođena koronavirusom (COVID-om 19).

U lipnju 2020. Vlada RH ovlastila je ministra financija za potpisivanje Sporazuma o dobrovoljnom jamstvu između Republike Hrvatske i Europske komisije za privremenu potporu radi smanjenja rizika od nezaposlenosti u izvanrednoj situaciji nakon izbijanja bolesti COVID-19, odnosno odobrila ulazak u program SURE. ${ }^{59}$

U daljnjem tekstu bit će prikazane dvije najčešće korištene mjere: skraćivanje radnog vremena te potpora za očuvanje radnih mjesta u djelatnostima pogođenima koronavirusom (COVID-om 19).

\subsubsection{Skraćivanje radnog vremena}

Ova mjera financira se iz, prethodno spomenutog, SURE programa. Potporu ${ }^{60}$ mogu koristiti poslodavci koji obavljaju gospodarsku djelatnost te zapošljavaju deset i više radnika. Temeljni kriterij kao uvjet za korištenje mjere jest očekivani pad ukupnog mjesečnog fonda radnih sati svih radnika zaposlenih kod poslodavca na puno radno vrijeme u mjesecu za koji se traži potpora od minimalno $10 \%$. Pored toga, poslodavac mora dokazati povezanost utjecaja epidemije COVID-a 19 na poslovanje i očekivanog pada ukupnog mjesečnog fonda radnih sati. Dokazom povezanosti Hrvatski zavod za zapošljavanje (dalje: HZZ) smatra pad prometa/ primitaka u svakom mjesecu za koji se traži potpora od najmanje $20 \%$ u odnosu na isti mjesec protekle godine i jednog od sljedećih razloga: pad narudžbi putem raskida ili izmjene ugovora s kupcem/kupcima, pismenim očitovanjem kupaca o padu narudžbi za mjesec za koji se traži potpora; nemogućnost ugovaranja novih poslova za vrijeme epidemije; nemogućnost isporuke gotovih proizvoda ili ugovorenih i plaćenih sirovina, repromaterijala, strojeva, alata; nemogućnost novih narudžbi sirovina, repromaterijala, alata i strojeva neophodnih za rad.

Dodjeljuje se za privremeno samo ako je došlo do skraćivanja mjesečnog fonda radnih sati više od $70 \%$. Visina subvencije iznosi najviše do 2800 kuna mjesečno neto po radniku.

\subsubsection{Potpora za očuvanje radnih mjesta u djelatnostima pogođenima COVID-om 19}

Ova potpora ${ }^{61}$ mogla bi se uvjetno rečeno nazvati „temeljnom“ mjerom, s obzirom na činjenicu da je od navedenih mjera prva našla svoju primjenu. Obuhvaća

59 Ministar financija Zdravko Marić tom je prilikom izjavio kako iznos jamstva iznosi 95,7 milijuna eura, a na temelju njega Hrvatska će iz spomenutog aranžmana moći ,povući” najmanje četiri puta veći iznos. Poslovni.hr/Hina. Hrvatska ulazi u EU-ov program očuvanja radnih mjesta SURE, 4. VI. 2020., dostupno na: https://www.poslovni.hr/hrvatska/hrvatska-ulazi-u-eu-ov-program-ocuvanja-radnih-mjestasure-4235688 (pristupljeno: 7. VIII. 2020.).

${ }_{60} \mathrm{http}: / / \mathrm{mjere} . \mathrm{hr} / \mathrm{admin} / \mathrm{wp}-\mathrm{content/uploads/2020/10/Skra \% C4 \% 87ivanje-radnog-vremena-22.10.-}$ UV.pdf (pristupljeno: 22. XI. 2020.).

${ }_{61}$ https://mjera-orm.hzz.hr/potpora-za-ocuvanje-radnih-mjesta-za-srpanj-kolovoz/ (pristupljeno 12. VIII. 2020.). 
najširi spektar poslodavaca koji je mogu zatražiti. Produljuje je, uz izmjene i dopune, Upravno vijeće HZZ-a. Zadnjom izmjenom (vrijedi za period od listopada do prosinca 2020.), ova je mjera obuhvatila i mikropoduzetnike za koje se do listopada predviđala odvojena mjera. Tako se sada ciljanom skupinom smatraju: određene taksativno navedene skupine poslodavaca (prijevoz i skladištenje, djelatnosti pružanja smještaja te pripreme i usluživanja hrane i pića, administrativne i pomoćne uslužne djelatnosti, umjetnost, zabava i rekreacija itd.); svi poslodavci koji ne mogu obavljati djelatnost sukladno Odlukama Stožera civilne zaštite (nacionalnog, županijskog, jedinica lokalne samouprave) ili kojima je na bilo koji način ograničen rad Odlukama Stožera civilne zaštite (nacionalnog, županijskog, jedinica lokalne samouprave), te mikropoduzetnici (poslodavci koji zapošljavaju manje od 10 radnika).

Visina potpore iznosi 4000 kuna mjesečno po radniku koji radi u punom radnom vremenu (iznimno 2000 kuna ako je poslodavac Odlukom Stožera zatvoren kraće od 14 dana), odnosno razmjerni dio po radniku prema broju sati rada u nepunom radnom vremenu prema postotku pada prihoda/primitaka te doprinos za mirovinsko osiguranje temeljem individualne kapitalizirane štednje proporcionalno iznosu potpore.

Poslodavci trebaju dokazati da su u razdoblju od 1. travnja do 30. rujna 2020. g. imali pad prihoda/primitaka u odnosu na isto razdoblje 2019., osim ako nisu mogli raditi zbog Odluka Stožera kada im se uspoređuju prihodi s rujnom 2019., no u tom slučaju mogu koristiti potporu samo za mjesec u kojem im je rad bio onemogućen.

\subsubsection{Zlouporabe potpora za očuvanje radnih mjesta}

Ubrzo nakon isplata prvih potpora za očuvanje radnih mjesta, pojavili su se i slučajevi njihovih zlouporaba od strane poslodavaca. Naime, postoji određen broj poslodavaca koji potpore koje primaju od države uopće ne isplaćuju radnicima, ili ih isplaćuju samo djelomično, ili plaću svode samo na visinu potpore ili dijela potpore. ${ }^{62}$ Zbog toga i zahtjev sindikalne središnjice Saveza samostalnih sindikata Hrvatske Vladi RH da HZZ potporu radnicima isplaćuje neposredno na njihove tekuće račune.

Problem je i u HZZ-u jer njihovi savjetnici premalo znaju o području radnih odnosa i onda ne daju dovoljno dobre informacije koje trebaju dati poslodavcu. “63

62 Kovačević Barišić, R., Čelnik SSSH-a: Uz sve mjere potpora, poslodavci krše prava radnika, od 1. IV. 2020., dostupno na: https://www.vecernji.hr/vijesti/celnik-sssh-a-uz-sve-mjere-potpora-poslodavcikrse-prava-radnika-1390870, (pristupljeno 14. VIII. 2020.); Nešto detaljnije je problematiku prezentirala i izvršna tajnica SSSH-a Ana Milićević Pazelj: „Oni poslodavci koji rade su trebali primiti samo potporu države $\mathrm{i}$ isplatiti pune plaće svojim radnicima, a u praksi to nije tako. To je naprosto nevjerojatno na koji način poslodavci dijele naknadu između sebe i radnika, svode plaću samo na visinu naknade, to nije bio niti smisao mjere. Vlasnici ili članovi uprava nisu predviđeni za naknadu, a imaju pravo za radnika, pa kaže pola meni pola tebi, ili kažu isplatit ću ti pola od 3250 kuna, a pola ću ostaviti za doprinose." SSSH, Pezelj: Nevjerojatno je na koji način poslodavci zlorabe potpore za radnike, 9. IV. 2020., dostupno na: http://www.sssh.hr/hr/vise/nacionalne-aktivnosti-72/pezelj-nevjerojatno-je-na-koji-nacin-poslodavcizlorabe-potpore-za-radnike-4305, (pristupljeno 14. VIII. 2020.).

63 SSSH, Pezelj: Nevjerojatno je na koji način poslodavci zlorabe potpore za radnike, o. c. 
Naime, postoji dužnost poslodavca da radnicima isplati plaću sukladno prethodnom utvrđenju temeljem ZR-a, kolektivnim ugovorom, pravilnikom o radu ili ugovorom o radu, neovisno o činjenici je li poslodavac ostvario potporu za očuvanje radnih mjesta. ${ }^{64}$ Poseban se problem javlja već pri odluci o dodjeli potpora za očuvanje radnih mjesta, jer podaci pokazuju da je potpore dobilo čak 15 posto poslodavaca koji su na listi poslodavaca koji ne isplaćuju plaće, iako je uvjet za dobivanje potpore nepostojanje duga. ${ }^{65}$

Zbog aktualnosti pandemijske situacije, ali i zbog neupućenosti radnika o vlastitim pravima, odnosno u zlouporabe kojima su podvrgnuti od strane poslodavaca, još uvijek ne postoji ni jedan primjer iz sudske prakse. Stoga predstoji čekati i vidjeti kakav će stav u ovakvim slučajevima zauzeti sudovi, ali i država te mogu li se očekivati adekvatne sankcije za one koji državne potpore zbog krizne situacije koriste kako bi postigli osobnu korist na štetu vlastitih radnika.

\section{PREGLED PRISTUPA DRUGIH DRŽAVA GLEDE MJERA ZA OČUVANJE RADNIH MJESTA}

\subsection{Republika Slovenija}

Slično kao i Republika Hrvatska, Republika Slovenija predstavila je zakonski paket mjera u svrhu financijske pomoći radnicima 2. travnja 2020. (s retroaktivnom primjenom od 13. ožujka) te ga je do trenutka pisanja ovoga rada dopunila i izmijenila još 4 puta. ${ }^{66}$

Inicijalnim paketom, ovisno o intenzitetu prestanka rada, predviđene su 3 mogućnosti:

1. Svim radnicima koji su ostali na radnim mjestima, država je uplaćivala naknade za mirovinsko osiguranje za travanj i svibanj.

2. Za slučaj privremenog prestanka rada (npr. dopusta) država se obvezala isplaćivati plaće u iznosu od $80 \%$ prosječne plaće radnika u protekla 3 mjeseca do visine prosječne plaće u Republici Sloveniji u 2019. godini te socijalne doprinose, ako poslodavac očekuje pad prihoda veći od $10 \% \mathrm{u}$ odnosu na 2019. godinu.

3. Radnici koji su ostali bez posla za vrijeme pandemije te nisu zadovoljavali uvjete za naknade za nezaposlene, primali su naknadu u iznosu od 513,64 eura bruto mjesečno.

64 A. B. Smije li poslodavac isplatiti radniku plaću manju od primljene potpore $i$ što s razlikom?, 14. V. 2020., dostupno na: https://www.rrif.hr/Smije_li_poslodavac_isplatiti_radniku_placu_manju_-1780vijest.html (pristupljeno 14. VIII. 2020.).

65 Spiljak, L., Dok neke tvrtke vraćaju novčanu pomoć, ima poslodavaca koji ne isplaćuju radnike, 13. VI. 2020., dostupno na: https://www.poslovni.hr/hrvatska/dok-jedne-tvrtke-vracaju-novcanu-pomocdrugi-poslodavci-dobivenim-novcem-ne-isplacuju-radnike-4236796 (pristupljeno 14. VIII. 2020.).

66 dostupno na: https://ec.europa.eu/info/sites/info/files/coronovirus_policy_measures_12_october. pdf (pristupljeno 14. XI. 2020.). 
Samozaposleni, poljoprivredni radnici i vjerski radnici koji su očekivali pad prihoda od barem $10 \%$ u odnosu na 2019., imali su pravo na fiksnu mjesečnu naknadu u iznosu od 350 eura za ožujak te 700 eura za travanj i svibanj, uz naknadu socijalnih doprinosa za travanj i svibanj. Posebna pozornost posvećena je radnicima koji su bili primorani ostati doma i brinuti se za svoju djecu zbog zatvaranja vrtića i škola ili zatvaranja javnog prijevoza i granica - njima je također osigurana naknada u visini od $80 \%$ plaće i socijalnih doprinosa.

Paketom mjera od 29. svibnja produljene su naknade plaća u slučaju privremenog prestanka rada, ali i uvedene mjere radi uvođenja programa skraćenog radnog vremena. Naime, poslodavcima koji ne mogu osigurati barem $90 \%$ uobičajenog obima posla za minimalno $10 \%$ zaposlenika, država će subvencionirati do 20 sati tjedno. U primjeni je do kraja 2020. godine.

Petim paketom od 23. rujna, osim produljenja trajanja postojećih mjera, ojačana je pomoć samozaposlenima i mikropoduzetnicima tako što im se daje pravo na mjesečni iznos od 1100 eura do kraja godine ako imaju pad prihoda od barem $30 \%$ u odnosu na 2019. godinu.

No, najzanimljivije novosti nastupaju uvođenjem sustava koji visinu naknade plaće na koju radnik ima pravo stavlja u odnos s njegovim ponašanjem i putovanjem u vrijeme pandemije. Pa tako pravo na naknadu od $100 \%$ plaće ima radnik koji je u karanteni zbog kontakta sa zaraženom osobom u sklopu radnog mjesta. Na 80-postotnu naknadu ima pravo onaj radnik koji je u karanteni po povratku iz zemlje sa zelene ili narančaste liste po opasnosti od zaraze u trenutku odlaska. Na $50 \%$ plaće koje bi dobio da je radio, a barem $70 \%$ minimalne plaće, ima pravo radnik koji je u karanteni jer je putovao u zemlju sa crvene liste zbog opravdanih razloga (smrt bračnog ili izvanbračnog druga, djeteta ili roditelja; rođenje djeteta; poziv na sud) uz prethodnu najavu poslodavcu. Ostali radnici koji se nalaze u karanteni zbog putovanja u države s crvene liste iz razloga koji nisu gore navedeni kao opravdani, nemaju pravo ni na kakvu naknadu plaće. ${ }^{67}$

\subsection{Republika Njemačka}

U trenutku pisanja ovoga rada, Njemačka ulazi u djelomični ekonomski lockdown u cilju sprečavanja tzv. drugog vala pandemije. Sukladno tome, mjere koje proglašava, više su gospodarske naravi - naknade i jednokratne potpore sa ciljem pomoći poduzećima u poslovanju čime se tek posredno ostvaruje učinak očuvanja radnih mjesta. ${ }^{68}$

Vlada se obvezuje poduzećima koja zapošljavaju manje od 50 radnika naknaditi $75 \%$ prihoda ostvarenog u studenome 2019., a onima s više od 50 zaposlenih do

67 Dodič, K., Miklavčič, D., The fifth COVID-19 Act adopted, 16. X. 2020., dostupno na: https://selih. si/en/covid-19-en/the-fifth-covid-19-act-adopted/ (pristupljeno 14. XI. 2020.).

68 ILO, Country policy responses, dostupno na: https://www.ilo.org/global/topics/coronavirus/ regional-country/country-responses/lang--en/index.htm\#DE (pristupljeno 15. XI. 2020.). 
$70 \%$. Uz to, kreditni program banke razvojne banke KfW u vlasništvu države bit će dostupan tvrtkama s manje od 10 zaposlenih. Samozaposleni i mali poduzetnici mogu primiti jednokratnu državnu pomoć ako dokažu povezanost gospodarskih poteškoća i krize izazvane COVID-om 19 te da je šteta nastala nakon 11. ožujka 2020.

Kao i mnoge druge države Europske unije, sukladno SURE programu, Njemačka provodi program skraćivanja radnog vremena. Pravo na naknade za provođenje programa imaju tvrtke u kojima barem jedna desetina radnika (uključujući privremene radnike) ima pad u količini posla, a država u potpunosti snosi i naknade socijalne sigurnosti (zdravstveno osiguranje, mirovinsko osiguranje i sl.). Visina naknade iznosi $60 \%$ dotadašnje neto plaće, ali za slučaj da mjera potraje, u 4. mjesecu provedbe raste na 70 odnosno na $80 \%$ od 7 . mjeseca provedbe sve do kraja 2021. godine. Olakšava se pristup naknadama za nezaposlene i produljuje razdoblje njihove isplate te se stvaraju mehanizmi potpore start-up tvrtkama i umjetnicima.

Glede poreza, porez na hranu u ugostiteljstvu do 30. lipnja 2021. snižava se sa 19 na $7 \%$. Ostala porezna olakšanja uključuju moratorij na porezne dugove i suspenziju sekvestracija.

\subsection{Republika Austrija}

U Republici Austriji i prije izbijanja pandemije bio je na snazi zakon koji uređuje postupanje u situaciji epidemije (Epidemiegesetz 1950.). Pojavom pandemije COVID-a 19 dopunjuje se kako bi njegove norme bile primjenjive i na trenutnu situaciju, što uključuje ovlast države glede proglašenja zatvaranja određenih djelatnosti radi sprečavanja širenja zaraze. Ovlasti po tome Zakonu idu toliko daleko da pod određenim uvjetima inspekcije smiju ulaziti i u domove stanovnika radi obavljanja testiranja i provođenja mjera ${ }^{69}$ Tim istim zakonom propisano je i pravo pravnih i fizičkih osoba na zahtijevanje naknade od države za slučaj pada prihoda prouzročenog jednim od propisanih razloga (bivanje u karanteni; život i rad u prostoru podložnom prometnim restrikcijama; rad na poslovima obuhvaćenima ograničenjima ili potpunim zatvaranjem; rukovođenje takvim poslovima).

Pored navedene postojeće zakonske regulative, od početka trenutne pandemije Republika Austrija se, poput Njemačke, odlučila na posrednu zaštitu radnih mjesta putem ekonomskih mjera naknade prihoda poduzećima uz provedbu mjera skraćenog radnog vremena sukladno SURE programu EU-a. ${ }^{70}$

Program skraćenog radnog vremena, u Austriji nazvan „Corona Kurzarbeit“, omogućava poduzećima u svim sektorima skraćivanje radnih sati od 10 do $90 \%$ na period od 6 mjeseci u slučaju gospodarskih poteškoća izazvanih pandemijom, ali

69 Coronavirus - Employment law update - Austria, dostupno na: https://www.eversheds-sutherland. com/global/en/what/articles/index.page?ArticleID=en/global/Austria/COVID-19-Coronavirus-whatcompanies-in-Austria-should-know (pristupljeno 22. XI. 2020.).

70 ILO, Country policy responses, dostupno na: https://www.ilo.org/global/topics/coronavirus/ regional-country/country-responses/lang--en/index.htm\#AT (pristupljeno 15. XI. 2020.). 
pod uvjetom da se prethodno postigne dogovor sa socijalnim partnerima, a razina broja zaposlenih ostane ista za vrijeme trajanja mjere i mjesec dana nakon njezina prestanka.

Također, olakšan je postupak prijave za naknade za nezaposlenost te povećan iznos naknade koja se odobrava obiteljima nižeg ekonomskog statusa ili čiji su članovi postali nezaposleni. Nezaposlenima se ujedno isplaćuje i jednokratna naknada u iznosu od 450 eura.

Planirana je i subvencija plaća u obliku ,novog startnog bonusa“, namijenjena zapošljavanju i brzom popunjavanju slobodnih mjesta, izračunata iz razlike između neto naknade za obavljeni posao i oko 80 posto neto naknade prije nezaposlenosti, uključujući doprinose za socijalno osiguranje do maksimalno 950 eura neto.

\subsection{Velika Britanija}

Nastupom pandemije Ujedinjeno Kraljevstvo se odlučilo, s jedne strane na donošenje paketa mjera koje do tada nisu postojale, ali i na prilagodbu već postojećih mjera socijalne sigurnosti novonastaloj situaciji.

U prvom redu, zakonska naknada za bolovanje (statutory sick pay - SSP) izmijenjena je na način da osobe na nju imaju pravo već od prvog dana izostanka s posla zbog bolesti, za razliku od prijašnjeg pravila po kojem su pravo ostvarivale tek nakon 4. dana. Također, u taj sustav dodaje se paket olakšica za mala i srednja poduzeća na način da se poslodavcu refundira do 2 tjedna isplaćene naknade za radnika koji je izbivao s posla zbog COVID-a 19. ${ }^{71}$

Radi pomoći samozaposlenima donesena je mjera pod nazivom Self-employment Income Support Scheme kojom se osobama na period do 3 mjeseca isplaćuje $70 \%$ prosječnih prihoda do iznosa od 2190 funti mjesečno. ${ }^{72}$

Glavna mjera u svrhu pomoći radnicima donesena je pod nazivom Coronavirus Job Retention Scheme. Donesena je početkom pandemije te produljivana nekoliko puta. Ova mjera trenutno pokriva $80 \%$ plaće radnika za sate koje nije radio (pri čemu je radnik morao biti odsutan s posla minimalno 7 uzastopnih dana), do visine od 2500 funti mjesečno. ${ }^{73} \mathrm{Uz}$ to, poslodavci koji su bili primorani zatvoriti radnje uslijed lockdowna ostvaruju pravo na 3000 funti mjesečne potpore. ${ }^{74}$

Velika Britanija posebnu je pozornost posvetila mladima s minimalnim radnim iskustvom odnosno onima koji ga tek trebaju steći, stoga je donijela i mjeru pod nazivom Kickstart Scheme. Njome se mladima od 16 do 24 godine kod kojih postoji

71 Statutory Sick Pay relief packages (SMEs), dostupno na: https://www.critchleys.co.uk/Briefings/ March-2020/Statutory-Sick-Pay-relief-package-for-small-and-me (pristupljeno 22. XI. 2020.).

72 Coronavirus - if you're self-employed, dostupno na: https://www.citizensadvice.org.uk/work/ coronavirus-if-youre-self-employed/ (pristupljeno 22. XI. 2020.).

73 Furlough Scheme Extended and Further Economic Support announced, 31. listopada 2020., dostupno na: https://www.gov.uk/government/news/furlough-scheme-extended-and-further-economicsupport-announced (pristupljeno: 22. XI. 2020.).

74 Ibid. 
rizik dugotrajne nezaposlenosti pokriva 100 posto nacionalne minimalne plaće za 25 radnih sati u tjednu, u trajanju do 6 mjeseci. ${ }^{75}$ Pored toga, omogućeni su i jednokratni iznosi u sklopu mjere Apprentice Scheme, odnosno Traineeship Scheme, no te se mjere primjenjuju samo na području Engleske. ${ }^{76}$

Ostale mjere donesene u cilju zadržavanja radnika na radnim mjestima i oporavka ekonomije obuhvaćaju: raznovrsne naknade za poduzeća i samozaposlene u ugostiteljstvu; Coronavirus Business Interruption Loan Scheme i Corona Large Business Interruption Loans Scheme kao mjere kojima se olakšavaju pristup i uvjeti pri bankovnim zajmovima i kreditima; produljenja rokova i olakšanja pri plaćanju poreza i $\mathrm{sl}^{77}$

\subsection{Republika Finska}

Finsko radno pravo odlikuju tri specifičnosti koje su utjecale na pristup Vlade Republike Finske pri kreiranju mjera za očuvanje radnih mjesta u doba pandemije:

1. veliki naglasak stavlja se na udruživanje poslodavaca i radnika u udruge do te mjere da se skoro svi propisi vezani uz radno pravo donose u procesu tripartitnog sudjelovanja Vlade, poslodavaca i radnika, uz napomenu da danas preko $70 \%$ Finaca pripada barem nekom obliku radničkog udruživanja. ${ }^{78}$ Tako sami radnici u Finskoj uplatama u razne fondove udruga po izboru osiguravaju sredstva za isplatu otpremnina u slučaju otkaza, naknada za nezaposlenost i drugih naknada iz područja socijalne sigurnosti.

2. Zakon o ugovoru o radu ${ }^{79}$ propisuje više mehanizama i obaveza poslodavaca kako bi otkaz ugovora o radu stvarno bio ultima ratio. To se postiže prvenstveno odredbama zakona kojima se poslodavcu nameće dužnost da na različite načina pokuša pronaći radniku adekvatan posao ili ga stručno usavrši za drugo radno mjesto prije nego se odluči na otkazivanje ugovora o radu. Također, propisuje se i institut tzv. lay-offa kojim se u posebnim slučajevima dopušta poslodavcu da radnicima izjavi privremeni prekid rada i ispostave plaće, ali da im pri tom ostala prava iz radnog odnosa (radni staž, pravo na godišnji i sl.) i dalje teku. Radnici obuhvaćeni takvom mjerom mogu po svom izboru u tom periodu primati naknade za nezaposlene ili započeti rad kod drugog poslodavca koji se prekida trenutkom prestanka lay-offa.

75 Kickstart scheme, 2. rujna 2020., dostupno na: https://www.gov.uk/government/collections/ kickstart-scheme (pristupljeno 22. XI. 2020.).

76 United Kingdom - Government and institution measures in response to COVID-19, 28. listopada 2020., dostupno na: https:/home.kpmg/xx/en/home/insights/2020/04/united-kingdom-government-andinstitution-measures-in-response-to-covid.html (pristupljeno 22. XI. 2020.).

77 https://www.ilo.org/global/topics/coronavirus/regional-country/country-responses/lang--en/index. htm\#GB (pristupljeno: 22. XI. 2020.).

78 http://reittikartta.valtikka.fi/en/labour-market-organisations/index.html (pristupljeno 15. VIII. 2020.).

79 Työsopimuslaki, 55/2001. 
3. Nadležna za financijsku pomoć građanima jest tzv. Kela ${ }^{80}$ (skraćeno od: Kansaneläkelaitos, odnosno na engleskom Social Insurance Institution), vladina agencija osnovana još 1937., koju prvenstveno financira država (75 $\%$ u 2017. godini), zatim uplate zdravstvenog osiguranja (19\%) te uplate lokalnih teritorijalnih jedinica $(6 \%),{ }^{81} \mathrm{~s}$ ciljem pružanja zdravstvenog i socijalnog osiguranja stanovnicima, studentima i radnicima u Finskoj. Osigurava raznovrsne socijalne i zdravstvene naknade ${ }^{82}$ (naknade roditeljima s djecom do 17. godine; naknade za samohrane roditelje; naknade za trošak vrtića, plaćanje najamnine studentima koji studiraju u inozemstvu i žive u unajmljenim stanovima, naknade za transport; subvencionirani obroci; naknade za liječenje i rehabilitaciju, invalidnine, naknade za slučaj smrti člana obitelji i dr.) te služi kao rezervni izvor naknada iz područja rada i socijalne sigurnosti za osobe koje nisu učlanjene u sindikate radnika ili su u njima već iskoristile svoja prava na naknade (naknada za nezaposlene, mirovine; naknade za životne i stambene troškove umirovljenika). Također, Kela isplaćuje i naknadu za nezaposlenost i za slučaj lay-offa u temeljnom iznosu od 33,66 eura dnevno za svaki radni dan, uz mogućnost povećanja iznosa pod određenim uvjetima (recimo slučaj ako nezaposlena osoba uzdržava maloljetnu djecu) ${ }^{83}$ a njeno maksimalno trajanje u pravilu iznosi 400 dana $^{84}$

Zbog svega navedenog i iznimno visoke razine zaštite radnika čak i u normalnim uvjetima, ne čudi da se pri donošenju mjera uslijed pandemije Republika Finska odlučila minimalno dirati u radno zakonodavstvo, a više se usmjeriti prema ekonomskim mjerama i preraspodjelama u državnom proračunu. Stoga se mjere u radnom zakonodavstvu svode na: ${ }^{85}$ produljenje otkaznog roka na 4 mjeseca u slučaju otkaza od strane zaposlenika u sektorima zdravstva, socijalnih službi, službi spašavanja i hitnim službama; produljenje obveze poslodavca da zaposli radnika kojem je uručio poslovno uvjetovani otkaz na 9 mjeseci nakon danog otkaza, ako se pokaže potreba za popunjavanjem tog radnog mjesta; privremeno dopuštanje uručivanja poslovno uvjetovanog otkaza radnicima koji su na probnom radu; privremeno dopuštanje obuhvaćanja u lay-off radnika s ugovorom na određeno vrijeme; privremeno skraćivanje vremena potrebnog za obavijest radnicima prije lay-offa sa 14 na 5 dana te skraćivanje vremena za pregovore s radnicima u slučaju lay-offa također na 5 dana.

80 https://www.kela.fi/web/en (pristupljeno 17. VIII. 2020.).

$81 \mathrm{https} / / /$ www.kela.fi/web/en/operations-funding (pristupljeno 17. VIII. 2020.).

82 https://www.kela.fi/web/en/operations-kela-benefits (pristupljeno 17. VIII. 2020.).

$83 \mathrm{https} / / /$ www.kela.fi/web/en/amount-of-the-unemployment-benefit (pristupljeno 17. VIII. 2020.).

${ }_{84} \mathrm{https}: / /$ www.kela.fi/web/en/quick-guide-to-unemployment-benefits (pristupljeno 17. VIII. 2020.).

85 Eurofund. Covid-19 EU PolicyWatch: Finland, dostupno na: https://static.eurofound.europa.eu/ covid19db/countries/FI.html (pristupljeno 17. VIII. 2020.). 
Neke promjene nastupile su i u naknadama koje osigurava Kela: ${ }^{86}$ sve do 1. siječnja 2021., radnik ima pravo na naknadu za nezaposlene odmah, a ne tek nakon 5 dana od početka nezaposlenosti; sve do kraja 2020. godine, period u kojem radnici primaju naknadu zbog otkaza ili lay-offa, neće se ubrajati u maksimalan broj dana za koji se dopušta isplaćivanje naknade; radnici više ne moraju raditi 26 tjedana kako bi ostvarili pravo na naknadu, nego 13 tjedana itd.

\section{ZAKLJUČNA RAZMATRANJA UZ PRIJEDLOGE DE LEGE FERENDA}

Većina država pogođenih krizom prouzročenom pandemijom COVID-a 19 od mjera usmjerenih na očuvanje radnih mjesta prije svega su koristile nove ili postojeće sheme skraćivanja radnog vremena. Ostale su uvele privremene potpore poslodavcima za isplatu plaća kako bi se promovirala retencija radnih mjesta. Potonja mjera jest bez presedana, a naišla je na široku primjenu među poslodavcima u svim državama. Procjenjuje se da je do sada oko 60 milijuna radnika u državama OECD-a bilo uključeno u navedenu mjeru. Dvije najvažnije mjere koje idu u prilog očuvanju radnih mjesta u ovoj krizi bez presedana su operabilne samo u nekim državama. Naime, u nekim državama primjenjuju se na radnike samo u nekim sektorima, u drugima se primjenjuju samo kratko vrijeme, u nekima dostupni resursi nisu dovoljni da pokriju sve radnike čija su radna mjesta ugrožena, dok u nekima ove mjere nisu ni predstavljene, niti se planiraju implementirati. Situaciju dodatno otežava činjenica da i u onim državama u kojima su mjere predstavljene poslodavci ih ne koriste. Razloga je nekoliko: u pitanju su poslodavci koji ih ne mogu koristiti jer ne mogu preživjeti krizu zbog nelikvidnosti i zatvaraju tvrtke ili ne zadovoljavaju uvjete za dobivanje mjera (najčešće SMS-tvrtke) ili jednostavno preferiraju zatvoriti tvrtku nego pregovarati oko primjena shema skraćivanja radnog vremena.

Neprecedentna uporaba shema za očuvanje radnih mjesta u velikoj je mjeri spriječila kolektivna otpuštanja radnika. ${ }^{87}$ Primjerice, uporaba resursa iz SURE programa sačuvala je oko 39,6 milijuna radnih mjesta. Procjenjuje se da bi povlačenje resursa iz spomenutog programa izravno utjecalo na gubitak oko 14 milijuna radnih mjesta, dok bi milijuni radnika osjetili značajno smanjenje plaće. ${ }^{88}$

Zabrinutost zbog potencijalno negativnog djelovanja shema za očuvanje radnih mjesta inicijalno je bila sekundarnog karaktera. No, i usprkos uloženom trudu u primjeni mjera za očuvanje radnih mjesta, s vremenom se otkrila i druga strana

$86 \mathrm{https}: / / \mathrm{www} . k e l a . f i / w e b / e n / u n e m p l o y m e n t-b e n e f i t-c o r o n a \#$ changes-in-unemployment-coverage (pristupljeno 17. VIII. 2020.).

87 OECD, Job retention schemes during the COVID-19 lockdown and beyond, dostupno na: https:// www.oecd.org/coronavirus/policy-responses/job-retention-schemes-during-the-covid-19-lockdown-andbeyond-0853ba1d/ (pristupljeno: 10. veljače 2021.).

${ }_{88}$ EU unemployment would double without job support schemes, dostupno na: https://www.etuc.org/ en/pressrelease/eu-unemployment-would-double-without-job-support-schemes (pristupljeno: 10. veljače 2021.). 
njihove medalje. Naime, radnici se još uvijek suočavaju s velikim brojem otkaza, neisplaćenim plaćama, nesigurnim uvjetima rada i zlouporabom i nepoštovanjem svojih temeljnih prava. Ovakva situacija stvara plodno tlo za dramatičnu socijalnu krizu koja se svakog trena može transformirati u ekonomsku krizu od koje će se većina država teško oporaviti.

Situaciju dodatno usložnjavaju pokušaji legislativne intervencije pojedinih država kojima se umanjuju prava radnika, njihova zaštita, posebice glede otkazivanja, radnog vremena, minimalne plaće, mogućnosti sklapanja kolektivnih ugovora i postizanja produktivnog socijalnog dijaloga. Za sada su sindikati na nacionalnoj razini predvođeni ETUC-om uspješno otklonili ovakve pokušaje pojedinih vlada.

Nadalje, značajno je istaknuti određene izazove s kojima se može suočiti u primjeni shema za očuvanje radnih mjesta. Naime, postoji opasnost da se javni resursi predviđeni za ovaj vid potpora namijene onim poslodavcima koji bi i bez primjene mjera sačuvali odnosna radna mjesta. Osim toga, sheme za očuvanje radnih mjesta mogu predstavljati svojevrsnu prepreku prijelazu radnicima u mnogo produktivnije tvrtke uz napomenu da je ova mogućnost u vrijeme lock downa osujećena restrikcijama vlada glede mogućnosti zapošljavanja novih radnika ukoliko otpuštaju stare. Stoga, kod primjene mjera za očuvanje radnih mjesta valja voditi računa da iste nisu usmjerene na potporu onih radnih mjesta za koja nije izgledno da će ostati sačuvana, jer se na taj način javlja rizik usporavanja postupka prijelaza radnika u druge produktivnije tvrtke i sektore, onemogućavajući pri tom agregatnu produktivnost i gospodarski razvoj. Stoga je kod implementacija mjera za očuvanje radnih mjesta nužno preciznije odrediti ciljane skupine, odnosno ona radna mjesta koja imaju rizik od gašenja zbog krize izazvane pandemijom COVID-a 19 , no koja su dugoročno isplativa. Naime, za neke je tvrtke potpuno razvidno da se neće oporaviti od krize i da će dugoročno gledano doći do neizbježnog i trajnog otpuštanja radnika. Takvim je radnicima nužno osigurati naknadu za nezaposlene u kombinaciji s aktivnom politikom tržišta rada koja će im omogućiti lakši prijelaz iz statusa nezaposlenosti u status zaposlenih osoba na isplativim poslovima. Kad je u pitanju potpora dugoročno neprofitabilnim radnim mjestima, države mogu tome doskočiti i pri tom uštedjeti vrijedne financijske resurse na način da od poslodavca traže da pokriju dio plaće radnika za neodrađene sate rada te da vremenski ograniče pružanje potpore. Također valja postaviti pitanje kada je vrijeme za povlačenje ili revidiranje mjera koje nude velikodušnu potporu kako iste ne bi proizvele negativne učinke. Na ovo pitanje dosta je teško dati odgovor s obzirom na činjenicu da je teško predvidjeti pojavu sljedećeg vala zaraze koronavirusom odnosno pojave njegovih novih sojeva. Ako bi se mjere povukle prerano, riskira se uništavanje radnih mjesta koja bi još mogla biti profitabilna te kolektivna otpuštanja radnika. $S$ druge strane, produžavajući lako dostupne mjere kojima se daje potpora za očuvanje radnih mjesta, riskira se očuvanje neprofitabilnih radnih mjesta, gubitak vrijednih resursa i usporava prijelaz odnosno zapošljavanje radnika u rastućim kompanijama i sektorima. 
U osnovi su vlade pristale na financiranje ovih mjera dok god postoje restrikcije kojima je svrha sprečavanje širenja virusa i zaštita zdravlja i života građana. No, u kojoj će mjeri države biti spremne odnosno voljne produljiti primjenu mjera i nakon ove inicijalne faze, ostaje nepoznato, što stvara određenu nesigurnost kako poslodavcima, tako i radnicima, posebice što odluke o tome mogu u velikoj mjeri biti utemeljene na političkim, a ne na gospodarskim okolnostima. Ovome se može doskočiti kreiranjem preciznog rasporeda korištenja mjera i određivanjem objektivnih kriterija za mogućnost njihove adaptacije.

Osim toga, važno je napraviti distinkciju između pojedinih sektora. Naime, postoje sektori odnosno gospodarske aktivnosti koji će se brzo oporaviti, ali s druge strane, i oni koji će neko dulje vrijeme ostati pod državnim restrikcijama, odnosno oni koji će trajnije osjećati negativne promjene u odnosu na potražnju svojih proizvoda odnosno usluga. Potonje će očigledno trebati produženu državnu potporu, čak i nakon normaliziranja gospodarske aktivnosti.

Nadalje, valja obratiti pozornost i na zlouporabu kratkotrajnih potpora poslodavcima nakon normalizacije gospodarske aktivnosti u kojoj radnici ponovno rade svoje ugovoreno puno odnosno nepuno radno vrijeme, a poslodavci i dalje apliciraju za potporu za neodrađene sate rada ili kada radnici te sate rada odrađuju kod kuće. Vlade ove zlouporabe mogu razriješiti kroz djelotvorniji rad inspekcije rada. Važno je napomenuti da skraćeno vrijeme rada poslodavci mogu iskoristiti za profesionalnu izobrazbu i usavršavanje radnika kako bi zadržali i unaprijedili svoje profesionalne vještine što će im po normalizaciji aktivnosti omogućiti produktivniji rad ili veću kompetitivnost na tržištu rada u slučaja gubitka radnog mjesta. Trošak izobrazbe radnika može biti podijeljen između poslodavca i države. ${ }^{89}$

Problemi koje predstavlja globalna pandemija za prava radnika tek su u povojima i nitko ne može sa sigurnošću reći kako će se dalje razvijati. Sukladno tome, niti ovim radom nije moguće dati decidirani odgovor na pitanje koje je metode i mjere najbolje primijeniti kako bi se osigurao što viši standard zaštite radnika. Za svaki od navedenih pristupa rano je suditi o učinkovitosti - mjere se primjenjuju relativno kratko, adaptiraju se novim situacijama i stanjem pandemije, a riječ je o problematici koja se uvijek dugo proteže te ne postoje brza rješenja. Isto tako, svaka zemlja razvijala se uz drugačiju mješavinu povijesnih, kulturoloških, socijalnih i ekonomskih elemenata, stoga primijeniti tuđa rješenja i očekivati identičan rezultat naprosto nije realan scenarij.

S obzirom na izmijenjenu situaciju na tržištu rada u Republici Hrvatskoj prouzročenu pandemijom COVID-a 19, očito je da će u skorijoj budućnosti morati nastupiti promjene u radnom zakonodavstvu pa bi bilo korisno promotriti što se od stranih mjera i rješenja može implementirati te iskoristiti ovu priliku da se prava radnika unaprijede dugoročno i kvalitetno, a ne samo za potrebe trenutne krize.

89 Bilić, A., „Functional Flexibility in the Context of Lifelong Learning“, u: Transnational, European, and National Labour Relations, Springer, 2018., str. 175-196. 


\section{LITERATURA}

\section{Knjige i članci}

1. Betten, L., International Labour Law, Kluwer, 1993.

2. Bilić, A., „Fleksibilni oblici rada i radno pravo“, Zb. Prav. fak. Sveuč. Rij. (1991.) v. 30, br. 2, 2009., str. 920-942.

3. Bilić, A., „Functional Flexibility in the Context of Lifelong Learning“, u: Transnational, European, and National Labour Relations, Springer, 2018., str. 175196.

4. Blanchard, O., Philippon, T., Pisani-Ferry, J., A new policy toolkit is needed as countries exit COVID-19 lockdowns, Policy contribution, issue no. 12, June 2020., Bruegel.

5. Blanpain, R., European Labour Law, Wolters Kluwer, 2012.

6. Blundell, R., Costa Dias M., Joyce, R., Xiaowei, X., „COVID $\square 19$ and Inequalities“, FISCAL STUDIES, vol. 41, no. 2, pp. 291-319 (2020).

7. Brent Orrell, A., Bishop, M. M., Hawkins, J., A Road Map to Reemployment in the COVID-19 Economy, empowering workers, employers, and states, American Enterprise Institute, July 2020.

8. Buklijaš, B., Bilić, A., Međunarodno radno pravo, Split, 2006.

9. Buklijaš, B., ,Prestanak radnog odnosa na inicijativu poslodavca prema konvenciji broj 158 Međunarodne organizacije rada“, Zbornik radova Pravnog fakulteta u Splitu, god. 30/1, 1993., str. 165-170.

10. Costa Dias, M., Joyce, R., Postel-Vinay, F., Xiaowei, X., „,The Challenges for Labour Market Policy during the COVID-19 Pandemic“, FISCAL STUDIES, vol. 41, no. 2, pp. 371-382 (2020.).

11. Gravelle, J. G.; Marples, D. J., Fiscal Policy and Recovery from the COVID-19 Recession (R46460), HeinOnline, Bluebook 21st. ed. 11 (July 29, 2020).

12. Houston, D., ,Local resistance to rising unemployment in the context of the COVID $\square 19$ mitigation policies across Great Britain“, Reg Sci Policy Pract. 2020; 12: 1189-1209.

13. Hupkau, C., Petrongolo, B., „Work, Care and Gender during the COVID-19 Crisis“, FISCAL STUDIES, 2020., vol. 41, no. 3, str. 623-651.

14. Mangan, D., „Covid-19 and Labour Law in Ireland“, European Developments, European Labour Law Journal, Vol. 11, Issue 3 (September 2020), str. 298-305.

15. Mangan, D., „Covid-19 and Labour Law in the United Kingdom“, European Developments, European Labour Law Journal, Vol. 11, Issue 3 (September 2020), str. 332-347.

16. Prassl, A. A., Cloyne, J., Costa Dias, M., Parey, M., Zilak, J. M., „The COVID $\square 19$ Economic Crisis“, FISCAL STUDIES, vol. 41, no. 3, pp. 489-492 (2020.).

17. T. von Wachter, „Lost Generations: Long-Term Effects of the COVID-19 Crisis on Job Losers and Labour Market Entrants, and Options for Policy“", FISCAL STUDIES, 2020., vol. 41, no. 3, str. 549-590.

18. Valticos, N., Potobsky von G., International Labour Law, Kluwer Law and Taxation Publishers, Deventer-Boston, 1995. 


\section{Mrežne stranice}

1. Coronavirus - Employment law update - Austria, dostupno na: https://www. eversheds-sutherland.com/global/en/what/articles/index.page?ArticleID=en/global/ Austria/COVID-19-Coronavirus-what-companies-in-Austria-should-know.

2. Coronavirus - if you're self-employed, dostupno na: https://www.citizensadvice.org. uk/work/coronavirus-if-youre-self-employed/.

3. Dodič, K., Miklavčič, D,. The fifth COVID-19 Act adopted, 16. X. 2020., dostupno na: https://selih.si/en/covid-19-en/the-fifth-covid-19-act-adopted/.

4. ETUC, Civil Society \& Trade Union Statement For a Europe that cares for all - during the COVID-19 pandemic and beyond, 22. IV. 2020., dostupno na: https://www.etuc. org/en/document/civil-society-trade-union-statement-europe-cares-all-during-covid19-pandemic-and-beyond.

5. ETUC, ETUC position on the proposal for revision of the Employment Guidelines, 12. VI. 2020., preuzeto sa: https://www.etuc.org/en/document/etuc-position-proposalrevision-employment-guidelines.

6. ETUC, Letter sent to EU Institutions on Emergency measures to save jobs and protect workers' rights in the European Union, 30. III. 2020., dostupno na: https://www. etuc.org/en/document/letter-sent-eu-institutions-emergency-measures-save-jobs-andprotect-workers-rights.

7. EU unemployment would double without job support schemes, dostupno na: https:// www.etuc.org/en/pressrelease/eu-unemployment-would-double-without-jobsupport-schemes.

8. Eurofund. Covid-19 EU PolicyWatch: Finland, dostupno na: https://static.eurofound. europa.eu/covid19db/countries/FI.html.

9. Furlough Scheme Extended and Further Economic Support announced, 31. listopada 2020., dostupno na: https://www.gov.uk/government/news/furlough-schemeextended-and-further-economic-support-announced.

10. Hrvatska gospodarska komora, 63 Mjere za pomoć gospodarstvu, 17. III. 2020., dostupno na: https://www.hgk.hr/63-mjere-za-pomoc-gospodarstvu.

11. Hrvatski zavod za zapošljavanje, Statistika Hrvatskog zavoda za zapošljavanje, dostupno na: https://statistika.hzz.hr/Statistika.aspx?tipIzvjestaja=1.

12. Hrvatski zavod za zapošljavanje. Mjesečni statistički bilten Hrvatskog zavoda za zapošljavanje za travanj 2020, svibanj 2020., dostupno na: https://www.hzz.hr/ content/stats/0420/HZZ_stat_bilten_04_2020.pdf.

13. http://mjere.hr/admin/wp-content/uploads/2020/10/Skra\%C4\%87ivanje-radnogvremena-22.10.-UV.pdf.

14. http://mjere.hr/mjere/javni-rad/.

15. http://www.sssh.hr/hr/vise/nacionalne-aktivnosti-72/pezelj-nevjerojatno-je-na-kojinacin-poslodavci-zlorabe-potpore-za-radnike-4305.

16. https://ec.europa.eu/commission/priorities/deeper-and-fairer-economic-andmonetary-union/european-pillar-social-rights_hr.

17. https://ec.europa.eu/croatia/about-us/semester_hr. 
18. https://ec.europa.eu/info/sites/info/files/coronovirus_policy_measures_12_october. pdf.

19. https://koronavirus.hr/.

20. https://koronavirus.hr/radni-odnosi-pitanja-i-odgovori/132.

21. https://mjera-orm.hzz.hr/potpora-za-ocuvanje-radnih-mjesta-za-srpanj-kolovoz/.

22. https://www.ilo.org/global/topics/coronavirus/regional-country/country-responses/ lang--en/index.htm\#GB.

23. https://www.kela.fi/web/en.

24. https://www.kela.fi/web/en/amount-of-the-unemployment-benefit.

25. https://www.kela.fi/web/en/operations-funding.

26. https://www.kela.fi/web/en/operations-kela-benefits.

27. https://www.kela.fi/web/en/quick-guide-to-unemployment-benefits.

28. https://www.kela.fi/web/en/unemployment-benefit-corona\#changes-inunemployment-coverage.

29. https://www.poslovni.hr/hrvatska/dok-jedne-tvrtke-vracaju-novcanu-pomoc-drugiposlodavci-dobivenim-novcem-ne-isplacuju-radnike-4236796.

30. https://www.poslovni.hr/hrvatska/hrvatska-ulazi-u-eu-ov-program-ocuvanja-radnihmjesta-sure-4235688.

31. https://www.rrif.hr/Smije_li_poslodavac_isplatiti_radniku_placu_manju_-1780vijest.html.

32. https://www.vecernji.hr/vijesti/celnik-sssh-a-uz-sve-mjere-potpora-poslodavci-krseprava-radnika-1390870.

33. ILO, Country policy responses, dostupno na: https://www.ilo.org/global/topics/ coronavirus/regional-country/country-responses/lang--en/index.htm\#DE.

34. ILO, Country policy responses, dostupno na: https://www.ilo.org/global/topics/ coronavirus/regional-country/country-responses/lang--en/index.htm\#AT.

35. ILOSTAT, https://ilostat.ilo.org./.

36. Internation Labour Organization, A policy framework for tackling the economic and social impact of the COVID-19 crisis, svibanj 2020., dostupno na: https:// www.ilo.org/wcmsp5/groups/public/@dgreports/@dcomm/documents/briefingnote/ wcms_745337.pdf.

37. International Labour Office, Global Employment Trends 2010; Ženeva, siječanj 2010, dostupno na: http://www.ilo.org/public/libdoc/ilo/P/09332/09332(2010-January).pdf.

38. International Labour Organization, ILO Standards and COVID-19(coronavirus) FAQ - Key provisions of international labour standards relevant to the evolving COVID-19 outbreak, 29.5.2020., dostupno na: https://www.ilo.org/wcmsp5/groups/public/---ed_ norm/---normes/documents/genericdocument/wcms_739937.pdf.

39. International Labour Organization. ILO Monitor: COVID-19 and the world of work. Fifth edition, 30.6.2020., dostupno na: https:/www.ilo.org/wcmsp5/groups/public/@ dgreports/@dcomm/documents/briefingnote/wcms_749399.pdf. 
40. ITUC, 2019, ITUC global rights indeks, https://www.ituc-csi.org/IMG/pdf/2019-06ituc-global-rights-index-2019-report-en-2.pdf.

41. Jungvirth, G., Koliko će recesije iz 2008. i 2020. biti drugačije i zašto je to važno, 24.3.2020, dostupno na: https://www.poslovni.hr/financije/kako-ce-recesije-iz-2008i-2020-biti-drugacije-i-zasto-je-to-vazno-4221453.

42. Kickstart scheme, 2. rujna 2020., dostupno na: https://www.gov.uk/government/ collections/kickstart-scheme.

43. Odluka o proglašenju epidemije bolesti COVID-19 uzrokovana virusom SARSCoV-2 od 11.3.2020., KLASA: 011-02/20-01/143, URBROJ: 534-02-01-2/6-20-01, preuzeto sa: https://zdravstvo.gov.hr/UserDocsImages/2020\%20CORONAVIRUS/ ODLUKA\%20O\%20PROGLA\%C5\%A0ENJU\%20EPIDEMIJE\%20BOLESTI\%20 COVID-19.pdf.

44. OECD, Job retention schemes during the COVID-19 lockdown and beyond, dostupno na: https://www.oecd.org/coronavirus/policy-responses/job-retention-schemesduring-the-covid-19-lockdown-and-beyond-0853ba1d/.

45. OECD. Unemployment rates, OECD - Updated: June 2020, dostupno na: http://www. oecd.org/newsroom/unemployment-rates-oecd-update-june-2020.htm.

46. Potpore za očuvanje radnih mjesta, dostupno na: https://mjere.hr/potpore-ocuvanjeradnih-mjesta-dokumentacija-obrasci/.

47. Prijedlog Uredbe Vijeća o uspostavi europskog instrumenta za privremenu potporu radi smanjenja rizika od nezaposlenosti u izvanrednoj situaciji (SURE) nakon izbijanja bolesti COVID-19 - dostupno na: https://eur-lex.europa.eu/legal-content/ HR/TXT/HTML/?uri=CELEX:52020PC0139\&from=EN.

48. Statutory Sick Pay relief packages (SMEs), dostupno na: https://www.critchleys. co.uk/Briefings/March-2020/Statutory-Sick-Pay-relief-package-for-small-and-me.

49. United Kingdom - Government and institution measures in response to COVID-19, 28. listopad 2020., dostupno na: https://home.kpmg/xx/en/home/insights/2020/04/ united-kingdom-government-and-institution-measures-in-response-to-covid.html.

\section{Pravni izvori}

1. Konvencija br. 168 o promicanju zapošljavanja i zaštiti od nezaposlenosti (Employment Promotion and Promotion Against Unemployment Convention), iz 1988. (No. 168.).

2. Konvencija Međunarodne organizacije rada o prestanku radnog odnosa na inicijativu poslodavca (Termination of Employment Convention), 1982. (No. 158).

3. Konvencija o radnicima s obiteljskim obvezama (Workers with Family Responsibilities Conventions), 1981. (No. 156).

4. Konvenciji br. 102 o najnižim standardima socijalne sigurnosti (Social Security (Minimum Standards) Convention, 1952. (No.102).

5. Preporuka br. 166 o prestanku radnog odnosa (Termination of Employment Recommendation, iz 1982. (No. 166). 
6. Prijedlog Uredbe Vijeća o uspostavi europskog instrumenta za privremenu potporu radi smanjenja rizika od nezaposlenosti u izvanrednoj situaciji (SURE) nakon izbijanja bolesti COVID-19.

7. Pročišćene verzije Ugovora o Europskoj uniji i ugovora o funkcioniranju Europske unije (2016/C 202/01).

8. Zakon o radu (NN 93/14, 127/17, 98/18).

9. Zakon o zaštiti pučanstva od zaraznih bolesti (NN 79/07, 113/08, 43/09, 130/17, 47/20).

\section{JOB RETENTION MEASURES IN THE TIME OF COVID-19 CRISIS}

In this paper, the authors discuss the issue of job preservation due to the crisis caused by the outbreak of the COVID-19 pandemic. They analyze the recommendations of the International Labor Organization and the European Trade Union Confederation and provide a comparative overview of measures to preserve jobs in several national legal orders. In their concluding remarks, they present the existing and potential problems arising from the application of the measures and provide solutions de lege ferenda.

Key words: COVID-19, jobs retention measures, International Labour Organisation, European Union, Republic of Croatia 